\title{
Overview of Student Knowledge,Attitudes, and Behaviors in Implementing Health Protocols During The Covid 19 Pandemi in UMJ Students 2021
}

\author{
${ }^{1}$ Arum Sri Ambarwati, ${ }^{2}$ Cut Nova Farhalida, ${ }^{3}$ Delika Puspita, ${ }^{4}$ Dhea Meditasari, ${ }^{5}$ Munaya \\ Fauziah \\ Faculty of Public Health, Muhammadiyah University of Jakarta \\ K.H. Ahmad Dahlan St, Cireundeu, Ciputat, South Tangerang, 15419 \\ E-mail: arum.saaa@gmail.com
}

\begin{abstract}
Covid 19 is a new type of coronavirus that causes respiratory tract infections in humans ranging from cold coughs to more serious ones such as Middle East Respiratory Syndrome (MERS) and Severe Acute Respiratory Syndrome (SARS) and is contagious. To stop the spread of covid 19, we must implement health protocols in our daily life. This study aims to determine the knowledge, attitudes, and behavior of health protocols from simple to Islamic concepts using qualitative methods with indepth online interviews taken from 4 UMJ student informants. It was found that there were still students who still did not believe in the existence of Covid-19, knowing that the riskiest spread of covid came from droplets or sneezing, students mentioned $3 M$ and $5 M$ as the health protocols they applied, but the most effective way of prevention is to reduce mobilization in the community. outside the home, in terms of Islam students also know how to maintain cleanliness following religious teachings and pray that this pandemic will end soon. From this research, in implementing the health protocol, UMJ students have implemented it quite well and correctly. The knowledge, attitudes, and behavior of UMJ students in responding to the COVID-19 pandemics are good, starting with implementing 5M, always maintaining cleanliness, and from an Islamic point of view, they understand well.
\end{abstract}

Keywords: Covid 19, Students, Knowledge, Behavior, Health Protocol, Attitude 


\author{
E-ISSN: 2808-5361 \\ http://e-journal.fkmumj.ac.id/
}

\section{Proceeding The First \\ Muhammadiyah Internasional- \\ Public Health and Medicine \\ Conference}

\section{INTRODUCTION}

Covid 19 is a new type of disease caused by infection with the Severe Acute Respiratory Syndrome Virus Covid 19 virus 2 (SARSCOV-2) or known as the novel Covid 19 virus (2019-nCoV). According to WHO (2020), Covid-19 is an infectious disease caused by a newly discovered type of coronavirus. This is a new virus and has never been identified to attack humans, before the outbreak in Wuhan, China, in December 2019 (Lomboan et al., 2020)

The Covid 19 pandemic has a major impact on public health, economy, society, and culture, this virus is easy to spread and infect anyone from young to old. Efforts to break the chain of the spread of COVID-19 require good knowledge and understanding from all elements of society. The importance of knowledge about covid 19 so that people can recognize, understand and take preventive measures so as not to cause an increase in the number of cases of the disease (Wonok et al., 2020). The preventive action that the Indonesian Ministry of Health has issued is a policy to implement 5M, namely wearing masks, washing hands with soap, maintaining distance, avoiding crowds, and reducing mobility.

The number of cases of covid 19 cases that occurred in the world as of Thursday, June 17, 2021, at 07.00 WIB. According to data from worldometers.info, there have now been 177,781,626 Covid-19 cases worldwide. A total of 162,279,376, of which 11,654,268 active cases worldwide were recorded. The country with the highest number of cases is occupied by the United States with a total of 34,365,215 cases.

In Indonesia, Indonesia has issued a disaster emergency response status, calculated from February 29, 2020, to May 29, 2020, related to this virus pandemic with a total time of 91 days. Indonesia recorded the addition of 12,624 new cases of Covid-19, Thursday (17/6/2021). The current total positive cases are 1,950,276. (Nugrahani, 2021)

Positive cases increased by 12,624 to $1,950,276$, recovered patients increased by 7,350 to $1,771,220$, patients died increased by 277 to 53,753 . It was recorded that 130,829 specimens were examined today throughout Indonesia, while the number of suspects was 110,472. (Alam, 2021)

With the increase in the number of Covid-19 cases which is increasing day by day with the importance of public knowledge, attitudes, and behavior towards the importance of implementing health protocols to reduce the number of Covid-19 cases.

Knowledge plays an important role in complete behavior because knowledge will form beliefs that will then perceive reality so that it affects behavior and attitudes (Untari \& Himawati, 2019). Knowledge can be measured by conducting interviews and questionnaires, in which the contents of the interview contain several questions related to the topic to be measured in the study.

Based on the description above, the researchers are interested in conducting this research regarding the description of the knowledge, attitudes, and behavior of UMJ students about the importance of health protocols in their area, so that they can be used as lessons so that we as students can increase awareness to the public about the importance of health protocols.

\section{METHODS}

This study aims to describe the knowledge, attitudes, and behavior of students in implementing health protocols during the COVID-19 pandemic for UUM students in 2021. This type of qualitative research uses a sample triangulation design approach to determine the description, attitudes, and behavior of students in implementing health protocols. This research was conducted on students at Umj in 2021 by collecting data via telecommunications

Qualitative research was conducted in May 2021-June 2021 using a descriptive observational study research design, namely conducting in-depth interviews using interview guidelines. In this study, there were four (4) students consisting of two (2) education study programs and two (2) public health faculty.

There are two types of data sources used in this study, namely primary data and secondary data. Primary data were obtained from direct observations in the field with questions using previously prepared 
guidelines, while secondary data were obtained from journals related to this research and regulations related to this research.

The validity of the data was carried out by the triangulation method, to maintain the validity of the data to determine the validity of the data in this study, the triangulation method was used. Method triangulation was carried out by using in-depth interviews with predetermined informants and reviewing documents from the description, attitudes, behavior of students in the knowledge of health protocols that had been made in previous studies, researchers used this triangulation to ensure the accuracy of the informants collected. The selection of categories, sub-categories, and codes has been discussed by all members of the research team.

Processing and analysis of qualitative data in this study were carried out with the data transcript stage where the data was transferred in the written form completely without changing, adding, or subtracting the information contained in the recording. Then a descriptive data analysis was carried out so that conclusions were obtained from the data that had been processed by coding each respondent's answers, as exemplified in table 1 .

\section{RESULTS AND DISCUSSIONS}

\section{Table 1 Results of Interview Data Analysis}

\begin{tabular}{|c|c|c|c|c|c|c|}
\hline No & Topic & Meaning units & Code & $\begin{array}{c}\text { Sub } \\
\text { Category }\end{array}$ & Category & Theme \\
\hline 1. & $\begin{array}{l}\text { How } \\
\text { do you resp } \\
\text { ond to } \\
\text { the COVID } \\
-19 \\
\text { pandemic } \\
\text { with } \\
\text { cases alway } \\
\text { s increasing } \\
?\end{array}$ & $\begin{array}{l}\text { 1. Responses me abo } \\
\text { ut pandemic } \\
\text { covid it yaa I worr } \\
\text { y so if the } \\
\text { case is ga going d } \\
\text { own so but if see o } \\
\text { f factors that exist } \\
\text { how would increas } \\
\text { e so hehe people } \\
\text { "it wrote ga discip } \\
\text { line within adherin } \\
\text { g to protocol } \\
\text { health -RN } \\
\text { 2. Because there may } \\
\text { be many people } \\
\text { who half believe } \\
\text { in the existence of } \\
\text { covid, while some } \\
\text { are talking about } \\
\text { just making } \\
\text { sense. So it does } \\
\text { not feel important } \\
\text { with what is meant } \\
\text { by the health } \\
\text { protocol. Like } 3 \mathrm{M} \text {, } \\
\text { that's because } \\
\text { there is an }\end{array}$ & $\begin{array}{l}\text { - } \\
\text { Worried, afrai } \\
d \text { that covid } \\
\text { cases will not d } \\
\text { ecrease } \\
\text { - a lot of } \\
\text { people, half } \\
\text { believe, } \\
\text { common sense, } \\
\text { feel } \\
\text { unimportant, } \\
\text { there are none }\end{array}$ & $\begin{array}{l}\text { - Level of } \\
\text { trust, artificial } \\
\text { importance }\end{array}$ & $\begin{array}{l}\text { - Artificial } \\
\text { interest } \\
\\
\text { Coronavir } \\
\text { us } \\
\text { is dangero }\end{array}$ & Covid 19 \\
\hline
\end{tabular}




\begin{tabular}{|c|c|c|c|c|c|c|}
\hline No & Topic & Meaning units & Code & $\begin{array}{c}\text { Sub } \\
\text { Category }\end{array}$ & Category & Theme \\
\hline & & $\begin{array}{l}\text { assumption that } \\
\text { covid is actually } \\
\text { between existing } \\
\text { and non- } \\
\text { existent. I believe } \\
\text { that covid exists } \\
\text { because we have } \\
\text { leaders whose } \\
\text { knowledge is } \\
\text { much higher than } \\
\text { ours, which they } \\
\text { also tell us to do to } \\
\text { prevent this } \\
\text { covid. So we } \\
\text { follow them. -AJ } \\
\text { 3. According } \\
\text { to my covid } 19 \text { is } \\
\text { a virus that } \\
\text { cannot because } \\
\text { of trivial at all the } \\
\text { people, because in } \\
\text { Indonesia itself m } \\
\text { any are already ex } \\
\text { posed through ma } \\
\text { ny were cured but } \\
\text { cannot be closed } \\
\text { the possibility } \\
\text { of the } \\
\text { virus was ga behin } \\
\text { d again so we as } \\
\text { a society should ju } \\
\text { st } \\
\text { follow prokes are } \\
\text { already in } \\
\text { the employ by the } \\
\text { government -AN } \\
\text { health, so covid fu } \\
\text { CM Response me abou } \\
\text { t covid further incr } \\
\text { eases caused beca } \\
\text { use people are incr } \\
\text { oasingly ignorant } \\
\text { rthe protocol of }\end{array}$ & $\begin{array}{l}\text { covid increase } \\
\text { d abai protocols } \\
\text { health }\end{array}$ & $\begin{array}{l}\text {-covid, health } \\
\text { protocol }\end{array}$ & $\begin{array}{l}\text { us } \\
\text { - } \\
\text { Covid, pres }\end{array}$ & \\
\hline
\end{tabular}


The COVID-19 pandemic has occurred for more than a year in Indonesia with an ever-increasing trend of cases, with many interrelated factors such as negligence, misunderstanding, lack of education and socialization, and so on. According to the results of in-depth interviews with research informants regarding the increasing trend of cases, it is conveyed as follows:

"My response to covid is increasing because people are increasingly ignoring health protocols, so that covid is increasing..." -CM FKM'18

Environmental conditions will also greatly affect the increase in Covid-19 cases as stated by one of the fellow students. "Because there are probably many people who half believe in the existence of Covid, while some say it's just a trick. So that they don't feel important about what is meant by the health protocol......." - AJ FIP'18

To find out the extent of the knowledge of fellow students about this covid, the writing team asked questions about the mechanism for the spread of covid-19, with the answers as follows:

"The spread of covid 19 is caused by splashing droplets (phlegm) then spreads into the air" - CD FKM'18

The government has set several rules regarding health protocols, and the following are the answers from informants. “...3M. Wash your hands, wear a mask and keep your distance. Only this time it has been updated to $5 \mathrm{M}$ because of the increasing number of covid cases, namely avoiding crowds and limiting mobility" - RN FKM'18.

As for another opinion, "The rules imposed by the government carry out $5 \mathrm{M}$ (washing hands, wearing masks, keeping distance, avoiding crowds, reducing mobility" -AN FIP'18.

There are several opinions regarding this prevention such as prevention so as not to be exposed or not to transmit. "My effort to prevent being exposed to the virus is to obey all the regulations implemented by the government to keep everyone safe"-AN FIP'18. Continuing the next statement, "........what I apply the most is when I want to leave the house if it's not important" don't go out of the house, but if it's urgent, keep your distance and always wear a mask, don't forget to wash your hands too" -RN FKM'18.

Several fellow students gave their comments regarding prevention of putting yourself in the position of being infected with Covid-19 to do, "......should just self-isolate, don't have to visit but just support each other..." -AJ FIP'18. The next statement is "Just carry out strict health protocols, and drink lots of immune vitamins" -CD FKM'18.

To stay closer to the Almighty, the team asked questions that touched on Islam, along with answers from fellow students. "In my opinion, we can only pray to Allah so that this virus ends quickly" AN FIP"18.

"In Islam, there is an example of a friend of the prophet who was hit by an epidemic, yes, in my opinion, he is always optimistic, has good prejudice, and prays that this will end soon. And always keep the cleanliness of the prayer cake, at first you have to do ablution in addition to cleaning your heart, you also clean yourself, according to you, especially Islam highly upholds cleanliness. Cleanliness is part of faith" -RN FKM'18.

Based on the results of research on the knowledge, attitudes, and behavior of UMJ students in implementing the health protocol for the spread of covid 19, it shows that UMJ students have good knowledge and understand the attitudes and behaviors that must be done to maintain health to avoid covid 19. This is also supported by research by (Sari et al., 2020) where the object of similar research is students.

Respondents received sources of information related to covid 19 through posters scattered on the street, socialization in the surrounding environment, and mostly obtained through social media, internet, and television. Currently, social media is a source of all information that has a major influence in shaping individual attitudes and behavior, especially now that we are entering the era of digitalization.

After the COVID-19 pandemic, there were changes in respondents' attitudes and behavior towards daily habits such as washing hands more often than usual, providing hand sanitizer, wearing masks when 
E-ISSN: 2808-5361

http://e-journal.fkmumj.ac.id/
Proceeding The First

Muhammadiyah Internasional-

Public Health and Medicine

Conference

leaving the house, keeping a distance from other people, staying away from crowds, and avoiding mobilization. In addition to taking care of yourself, the application of health protocols can also break the chain of transmission of covid 19

Although indeed not all individuals in the surrounding environment are obedient to health protocols, due to the lack of warnings in the surrounding environment and policymakers as well as the lack of awareness and knowledge of the individuals themselves, therefore the importance of socialization and there needs to be self-awareness to obtain information about this covid 19. through social media, the internet, and television to view infographics and the latest news.

The application of the health protocol is also in line with Islamic principles in which Allah SWT always reminds us to maintain cleanliness, in addition to trying to avoid the covid 19 viruses, maintaining cleanliness is also a form of our faith in Allah SWT.

In Islam, washing hands is one of the recommendations in cleanliness when you want to perform ablution, which begins with washing your hands and then is accompanied by washing other body parts according to the sequence in ablution. One of the efforts that can be done in preventing COVID-19 is to always maintain cleanliness and this is in line with Islamic teachings. (Pulungan, 2020)

\section{CONCLUSIONS AND SUGGESTIONS}

In implementing the health protocol, UMJ students have implemented it quite well and correctly. The knowledge, attitudes, and behavior of UMJ students in responding to the COVID-19 pandemic are good, starting with implementing 5M, always maintaining cleanliness, and from an Islamic point of view, they understand well.

We hope that the results of this research can make the government more socialize/provide education on the importance of this health protocol to the public to increase public awareness of the importance of health protocols.

\section{REFERENCES}

1. Alam, S. O. (2021). DKI Tembus 4 Ribu! Ini Sebaran 12.624 Kasus Baru COVID-19 RI 17 Juni. Detik Health. https://health.detik.com/berita-detikhealth/d-5609933/dki-tembus-4-ribu-ini-sebaran12624-kasus-baru-covid-19-ri-17-juni

2. Lomboan, M. V, Rumayar, A. A., \& Mandagi, C. K. . (2020). Gambaran Persepsi Masyarakat Tentang Pencegahan Covid-19 Di Kelurahan Talikuran Utara Kecamatan Kawangkoan Utara. Kesmas, 9(4), 111-117.

3. Nugrahani, A. W. (2021). Update Corona Global 17 Juni 2021: Total Kasus Covid-19 di Seluruh Dunia Lebih dari 177,7 Juta. Tribun News. https://www.tribunnews.com/corona/2021/06/17/updatecorona-global-17-juni-2021-total-kasus-covid-19-di-seluruh-dunia-lebih-dari-1777-juta

4. Pulungan, S. (2020). COVID 19 DALAM PERSPEKTIF FIQIH (Studi Kasus Trapi Covid Tentang Kebersihan). Qiyas : Jurnal Hukum Islam Dan Peradilan, 5(2), 123-127.

5. Sari, D. N. A., Setyawan, A., Supriyadi, \& Purwitaningtyas, R. Y. (2020). Pengetahuan Mahasiswa Baru Keperawatan Tentang Protokol COVID-19. Jurnal Keperawatan, 12(4), 711-718.

6. Untari, S., \& Himawati, L. (2019). TINGKAT PENGETAHUAN REMAJA TENTANG COVID-19 DI DESA MAYAHAN. PENINGGALAN SEJARAH SEBAGAI SUMBER BELAJAR SEJARAH DALAM PENANAMAN NILAI-NILA KEBANGSAAN PENDAHULUAN Banyuwangi Merupakan Wilayah Yang Memiliki Beberapa Daerah Yang Berpotensi Memiliki Situs Peninggalan Sejarah Yang Sampai Saat Ini Masih Ada Namun Kondisi, 1(1), 41-57. http://www.ghbook.ir/index.php?name=\$نى \& ذ وي ن/\&option=com_dbook\&task=readonline\&book_id=13650\&page=73\&chkhashk=ED9C9491B4\& Itemid=218\&lang=fa\&tmpl=component\%0Ahttp://www.albayan.ae\%0Ahttps://scholar.google.co.id/s cholar?hl=en\&q=APLIKASI+PENGENA

7. Wonok, M. J., Wowor, R., \& Tucunan, A. A. T. (2020). Gambaran Perilaku Masyarakat Tentang Pencegahan Covid-19 Di Desa Tumani Kecamatan Maesan Kabupaten Minahasa Selatan. Jurnal KESMAS, 9(7), 147-156. 